\title{
A new device to mount portable energy-dispersive $X$-ray fluorescence spectrometers (p-ED-XRF) for semi-continuous analyses of split (sediment) cores and solid samples
}

\author{
Philipp Hoelzmann, Torsten Klein, Frank Kutz, and Brigitta Schütt \\ Physical Geography, Institute of Geographical Sciences, Department of Earth Sciences, \\ Freie Universität Berlin, Berlin, Germany \\ Correspondence to: Philipp Hoelzmann (philipp.hoelzmann@fu-berlin.de) \\ Received: 20 October 2016 - Discussion started: 8 November 2016 \\ Revised: 19 January 2017 - Accepted: 30 January 2017 - Published: 17 February 2017
}

\begin{abstract}
Portable energy-dispersive X-ray fluorescence spectrometers ( $\mathrm{p}-\mathrm{ED}-\mathrm{XRF}$ ) have become increasingly popular in sedimentary laboratories to quantify the chemical composition of a range of materials such as sediments, soils, solid samples, and artefacts. Here, we introduce a low-cost, clearly arranged unit that functions as a sample chamber (German industrial property rights no. 202014106 048.0) for p-ED$\mathrm{XRF}$ devices to facilitate economic, non-destructive, fast, and semi-continuous analysis of (sediment) cores or other solid samples. The spatial resolution of the measurements is limited to the specifications of the applied p-ED-XRF device - in our case a Thermo Scientific Niton XL3t p-ED-XRF spectrometer with a maximum spatial resolution of $0.3 \mathrm{~cm}$ and equipped with a charge-coupled device (CCD) camera to document the measurement spot. We demonstrate the strength of combining p-ED-XRF analyses with this new sample chamber to identify Holocene facies changes (e.g. marine vs. terrestrial sedimentary facies) using a sediment core from an estuarine environment in the context of a geoarchaeological investigation at the Atlantic coast of southern Spain.
\end{abstract}

\section{Introduction}

Bulk-sediment chemistry data of split-core sediment surfaces provided by non-destructively measured portable $\mathrm{X}$ ray fluorescence (XRF) are important for the determination of sedimentary composition, the interpretation of varying facies, and thus the reconstruction of environmental conditions.
Therefore, computer-controlled core-scanning XRF tools are often successfully applied (Jansen et al., 1998; Koshikawa et al., 2003; Kido et al., 2006; Richter et al., 2006) and supply bulk-sedimentary data at nearly continuous micron-scale resolution, first of all for environments that provide highly resolved archives with low sediment accumulation rates such as in cores from marine or lacustrine environments. However, these instruments are extremely cost-intensive, and especially terrestrial sediments (e.g. laminated or homogenous) often show a lower temporal resolution that justifies the application of basic XRF instruments with much lower spatial resolution.

This paper introduces a hands-on, low-cost device that uses common adapters to mount portable energy-dispersive X-ray fluorescence ( $\mathrm{p}$-ED-XRF) devices so that these can provide bulk-sedimentary chemistry data from nondestructive measurements at the surface of a split sediment core or from other solid samples at a spatial resolution from $0.3 \mathrm{~cm} \times 0.3 \mathrm{~cm}$ to $0.8 \mathrm{~cm} \times 0.8 \mathrm{~cm}$. Our device bridges the gap between sophisticated, computer-controlled corescanning XRF systems with the highest spatial resolution and simple manually performed hand-held p-ED-XRF analyses. We demonstrate the strength of combining p-ED-XRF analyses with this new sample chamber to identify Holocene facies changes (e.g. marine vs. terrestrial sedimentary facies) using a sediment core from an estuarine environment in the context of a geoarchaeological investigation. At the archaeological site Ayamonte (southern Spain), located at the estuary where the Guadiana River flows into the Atlantic in the southwest of the Iberian Peninsula, sediment archives were investigated in order to provide input for an improved environmental re- 
construction of the Holocene settling phases. We focus here on (i) the technical description of the newly introduced device; (ii) how bulk-sedimentary chemistry data were obtained at centimetre resolution by p-ED-XRF, and (iii) how these data were used as an integral measure to differentiate estuarine/lagoonal from terrestrial facies in a series of sediment drillings of up to $900 \mathrm{~cm}$ depth. We present quantitative element data at approximately $1 \mathrm{~cm}$ resolution from one of the analysed sediment cores to point out the low-cost, fast, nondestructive, and accurate results obtained with the mounted p-ED-XRF spectrometer.

\section{Study site, material, and methods}

\subsection{Study Site}

The new discovery of the Phoenician necropolis and colony Ayamonte opened a new chapter in Phoenician research at the southwestern coasts of the Iberian Peninsula (Teyssandier and Marzoli, 2014). To contribute towards an understanding of the utilization of the ancient settlement, initial studies focus of a possibly rearward harbour location within the lagoonal-like environments of the "Estuario de la Nao". Sediment drillings were radiocarbon-dated and analysed for their sedimentological and geochemical composition.

The study site is located in the Spanish province of Huelva at the Atlantic coast in the southwest of the Iberian Peninsula and comprises the small tributary Estuario de la Nao, which discharges into the lower Guadiana estuary, located approximately $3 \mathrm{~km}$ north of the city of Ayamonte. AYA05 $\left(37^{\circ} 14^{\prime} 4.61^{\prime \prime} \mathrm{N}, 7^{\circ} 23^{\prime} 45.38^{\prime \prime} \mathrm{W}\right)$ is a core of a series of three drilling sites (Fig. S1 in the Supplement) and is located at the foot slope of a hoof-shaped hillside within a salt marsh area, which is inundated during spring high tides (Fletcher, 2005). The Estuario de la Nao drains an area of approximately $10 \mathrm{~km}^{2}$, and its floodplain contains agricultural, industrial, and semi-natural environments. A detailed report with the geoarchaeological results has been published in Klein et al. (2016). Here, we focus on the analyses that were performed with the newly designed sample chamber with the mounted p-ED-XRF spectrometer to support sedimentary facies differentiation.

\subsection{Material}

The sediment core AYA05 has a total depth of $900 \mathrm{~cm}$ and consists of organic-rich, very carbonate-poor grey (7Y 5/1) to greyish-brown (8.5YR 5/2) pure silt (Fig. S2). Distinct layers of marine fauna, macro-botanical remains, and charred wood occur as well as four layers with broken shell material (at 7.20 to $7.12 \mathrm{~m}$ below surface (m b.s.); 6.85 to $6.75 \mathrm{~m}$ b.s.; 6.35 to $5.80 \mathrm{~m}$ b.s.; 5.65 to $5.30 \mathrm{~m}$ b.s.). The age model for core AYA05 consists of five stratigraphic radiocarbon dates from charred wood or plant remains that show no age inversions and cover the period from ca. 5000 to $3000 \mathrm{cal} \mathrm{BP}$.
For a detailed description of all cores and corresponding age models, refer to Klein et al. (2016).

For the p-ED-XRF measurements no laborious core preparations were necessary. The $1 \mathrm{~m}$ long core sections were split into two halves: an air-dried half was covered with a mylar foil $(0.4 \mu \mathrm{m}$ thick $)$, transferred to the $\mathrm{ASC}^{\circledR}$ manual core track with the mounted sample chamber, and after the p-EDXRF spectrometer was fixed to the sample chamber the core was ready for analysis.

\subsection{Methods}

The sample chamber that holds the measurement system (e.g. p-ED-XRF spectrometer; Fig. 1a) for the analysis of sediment and drill core samples comprises a housing base and housing cover. Both base and cover are equipped with cladding and are constructed so that they form a plug-in device (Anonymous, 2014) that consists of radiation shielding material (metal alloy). The cladding of the housing base and the housing cover has an opening with a lead-through for the holding fixture of the split sediment or drill core. In order to analyse the samples, there is an aperture in the bottom of the housing cover for the arrangement of the measurement system. The analyser or measurement system is placed above the sample so that, in the case of XRF spectrometers, the X-ray source is directed from the top down on the split sediment or drill core or solid sample (Fig. 1b). The distance between the XRF spectrometer and the sample should be minimized and can be adjusted manually with adjusting screws (Fig. 1a). Measurements may be performed with or without a foil as protection (e.g. polypropylene $4 \mu \mathrm{m}$ thick). In the analyses presented here measurements were performed without a foil and with a distance of $1 \mathrm{~mm}$ between the XRF spectrometer and the sample. Cores of undefined length or solid samples can be passed through the sample chamber on the holding track.

The $\mathrm{ASC}^{\circledR}$ manual core track (http://www.ascscientific. com/mantrack.html) accommodates the dried and split sediment cores, so these slide in a low friction track and are positioned at each measurement point by the operator. The sample chamber is adjusted to the core track in such a way that quasi-continuous measurements at a spatial resolution down to $0.3 \mathrm{~cm} \times 0.3 \mathrm{~cm}$ become possible for different types of samples, cores, or " $u$-channels" (Fig. 2).

Our measurements were performed using a Thermo Scientific Niton XL3t p-ED-XRF spectrometer equipped with a charge-coupled device (CCD) camera to document the measurement spot and a semi-conductor detector for the detection of the XRF. A spatial resolution of $0.8 \mathrm{~cm} \times 0.8 \mathrm{~cm}$ was selected for the analyses. The following measurement conditions were applied: 


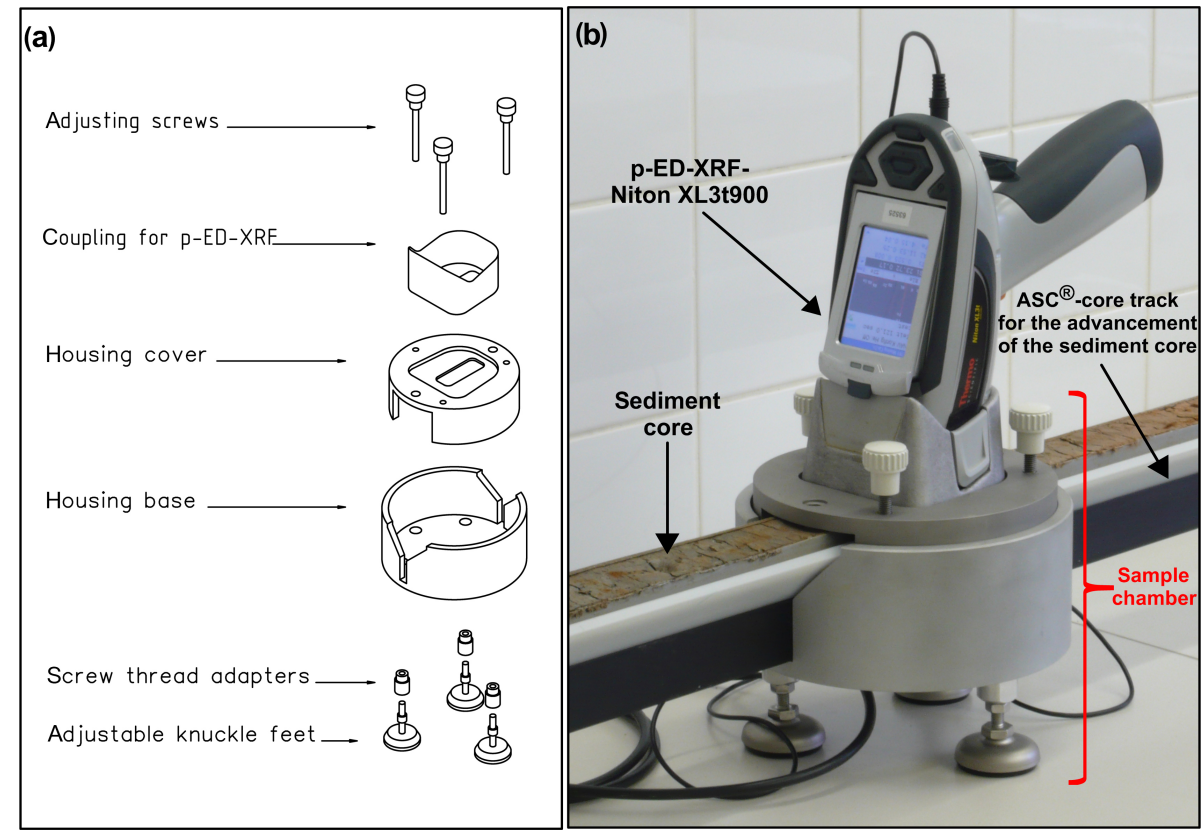

Figure 1. (a) Engineering drawing of the sample chamber; (b) p-ED-XRF spectrum analyser (here Thermo Scientific Niton XL3t 900) mounted to the sample chamber (German industrial property right no. 202014106048.0 ) for measuring a sediment core within the ASC ${ }^{\circledR}$ core track.

$\begin{array}{ll}\text { X-Ray source: } & \text { Ag-anode } \\ \text { Umax } \times \text { Imax: } & 2 \mathrm{~W} \\ \text { Umax: } & 40 \mathrm{kV} \\ \text { Imax: } & 100 \mu \mathrm{A} \\ \text { Used } & \text { Main } \\ \text { filters/elements: } & \end{array}$

(without filters) $30 \mathrm{~s}$ at $50 \mathrm{kV}$ with $40 \mu \mathrm{A}$ $\mathrm{Ti}, \mathrm{V}, \mathrm{Cr}, \mathrm{Mn}, \mathrm{Fe}, \mathrm{Co}$, $\mathrm{Ni}, \mathrm{Cu}, \mathrm{Zn}, \mathrm{As}, \mathrm{Se}$, $\mathrm{Rb}, \mathrm{Sr}, \mathrm{Hf}, \mathrm{Ta}, \mathrm{W}, \mathrm{Re}$, $\mathrm{Pb}, \mathrm{Bi}$

Low (with stacked foil filters; specification not revealed by Niton) $30 \mathrm{~s}$ at $20 \mathrm{kV}$ with $100 \mu \mathrm{A} \mathrm{S}, \mathrm{K}, \mathrm{Ca}$

Light (with stacked foil filters; specification not revealed by Niton) $30 \mathrm{~s}$ at $8 \mathrm{kV}$ with $250 \mu \mathrm{A} \mathrm{Mg}, \mathrm{Al}, \mathrm{Si}$, $\mathrm{P},(\mathrm{S}), \mathrm{Cl},(\mathrm{K}),(\mathrm{Ca})$, (Ti), (V), (Cr)

High (with stacked foil filters; specification not revealed by Niton) $30 \mathrm{~s}$ at $50 \mathrm{kV}$ with $40 \mu \mathrm{A} \mathrm{Zr}, \mathrm{Nb}, \mathrm{Mo}$, $\mathrm{Pd}, \mathrm{Ag}, \mathrm{Cd}, \mathrm{Sn}, \mathrm{Sb}$, $\mathrm{Ba}$

He-atmosphere: No

A typical measurement cycle with the p-ED-XRF spectrum analyser starts after the core description, which is a premise for the adequate choice of certified reference material (CRM) for the calibration of the XRF spectrometer, and consists of the calibration itself, the semi-continuous analyses of the core or sample, and lastly by an evaluation of the results (Fig. 3).

A CRM lake sediment LKSD-2 (Lynch, 1990) was prepared in a sample cup and measured under identical measurement conditions. Only elements that show mean values larger than 4 times the $2 \sigma$ error of the measurements ( $\mathrm{Al}, \mathrm{Ca}$, $\mathrm{Cl}, \mathrm{Fe}, \mathrm{K}, \mathrm{Pb}, \mathrm{Rb}, \mathrm{S}, \mathrm{Si}, \mathrm{Sr}, \mathrm{Ti}, \mathrm{V}, \mathrm{Zn}$ ) were taken into account for the analyses (Schwanghart et al., 2016). Typical recovery values for these elements of a lake sediment (CRM LKSD2; Lynch, 1990) and a stream sediment (CRM GBW07312) vary from 88.6 to $116.9 \%$ depending on the element and its concentration (Fig. 4). For the CRM LKSD-2 we obtained the following recovery values for the elements that were used in our study (in brackets certified concentrations):

$\begin{array}{llr}\mathrm{SiO}_{2} & (58.9 \%) & 101.2 \text { to } 103.2 \% \\ \mathrm{CaO} & (2.2 \%) & 100.5 \text { to } 102.5 \% \\ \mathrm{Fe}_{2} \mathrm{O}_{3} & (6.24 \%) & 99.6 \text { to } 101.0 \% \\ \mathrm{~S} & (0.14 \%) & 89.3 \text { to } 109.3 \% \\ \mathrm{Ti} & \left(3460 \mu \mathrm{g} \mathrm{g}^{-1} \mathrm{dw}\right) & 98.0 \text { to } 100.9 \% \\ \mathrm{Cl} & \left(163 \mu \mathrm{g} \mathrm{g}^{-1} \mathrm{dw}\right) & 93.0 \text { to } 104.2 \%\end{array}$

In our example, in total 823 measurements were performed with the mounted $\mathrm{p}$-ED-XRF spectrometer for the $900 \mathrm{~cm}$ long core AYA05. To enhance accuracy, each single measurement took $120 \mathrm{~s}$, while manual replacement of the 

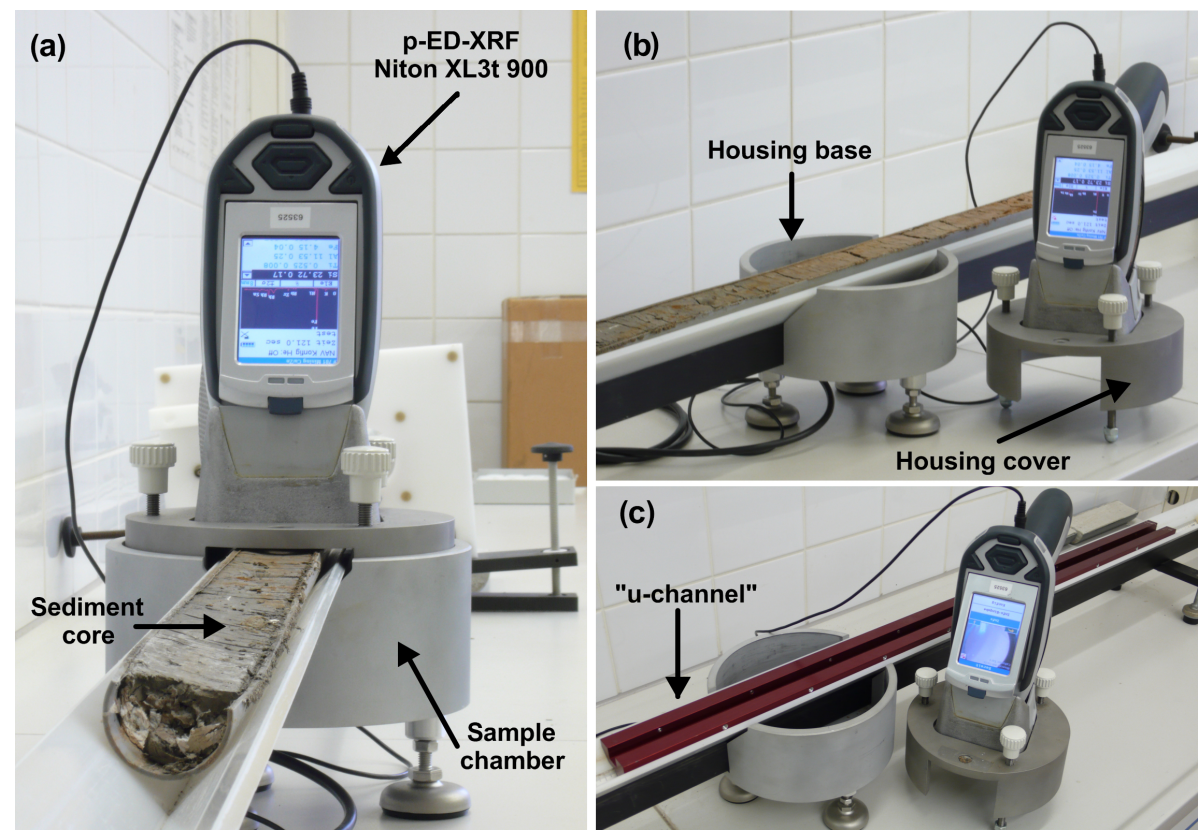

Figure 2. (a) p-ED-XRF spectrum analyser fixed to the sample chamber to analyse a split sediment core; (b) view of the housing base with the lead-through for the split sediment core and the p-ED-XRF spectrum analyser fixed to the housing cover; (c) same as (b) but with a " $u$-channel" often used in palaeolimnological investigations.

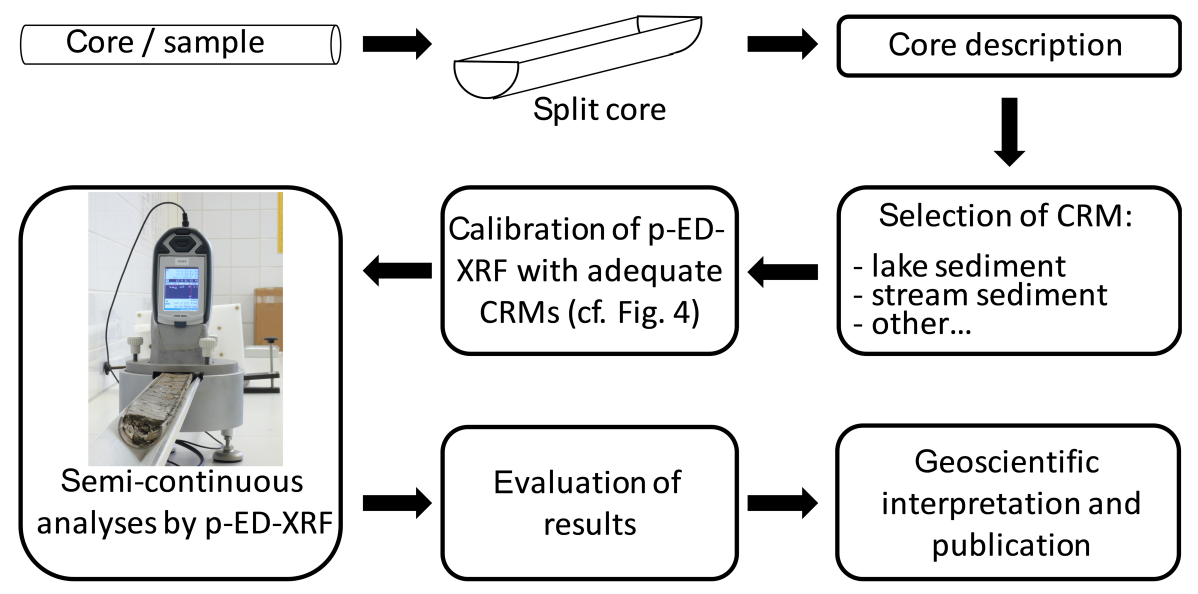

Figure 3. Schematic flow chart for a typical measurement cycle.

core for the subsequent analysis is conservatively calculated at $30 \mathrm{~s}$, so that the overall measurement time totals approximately $35 \mathrm{~h}$.

The sediment colour was determined using a Munsell soil colour chart. The TC (total carbon) content was analysed with a LECO TruSpec CHN analyser by dry combustion at $950^{\circ} \mathrm{C}$ of $0.1 \mathrm{~g}$ of homogenized and dried sediment samples in an oxygen atmosphere followed by IR detection of the evolved $\mathrm{CO}_{2}$. For the determination of the total inorganic carbon (TIC) content, $\mathrm{CO}_{2}$ was evolved during hot $\left(70^{\circ} \mathrm{C}\right)$ acid $\left(\mathrm{H}_{3} \mathrm{PO}_{4}\right)$ treatment from $0.1 \mathrm{~g}$ of dried and homogenized sediment samples. Quantification was performed with a Woesthoff Carmhograph C-16 by measuring the change in conductivity caused by the evolved $\mathrm{CO}_{2}$ in $20 \mathrm{~mL}$ of a $0.05 \mathrm{~N} \mathrm{NaOH}$ solution. The total organic carbon (TOC) was calculated by subtracting TIC from TC.

\section{Results and discussion}

\subsection{Facies interpretation of core AYA05 using p-ED-XRF analysis}

Three units (unit I from 9.00 to $2.30 \mathrm{~m}$ b.s.; unit II from 2.30 to $0.93 \mathrm{~m}$ b.s.; unit III from $0.93 \mathrm{~m}$ b.s. to the top of the core) 


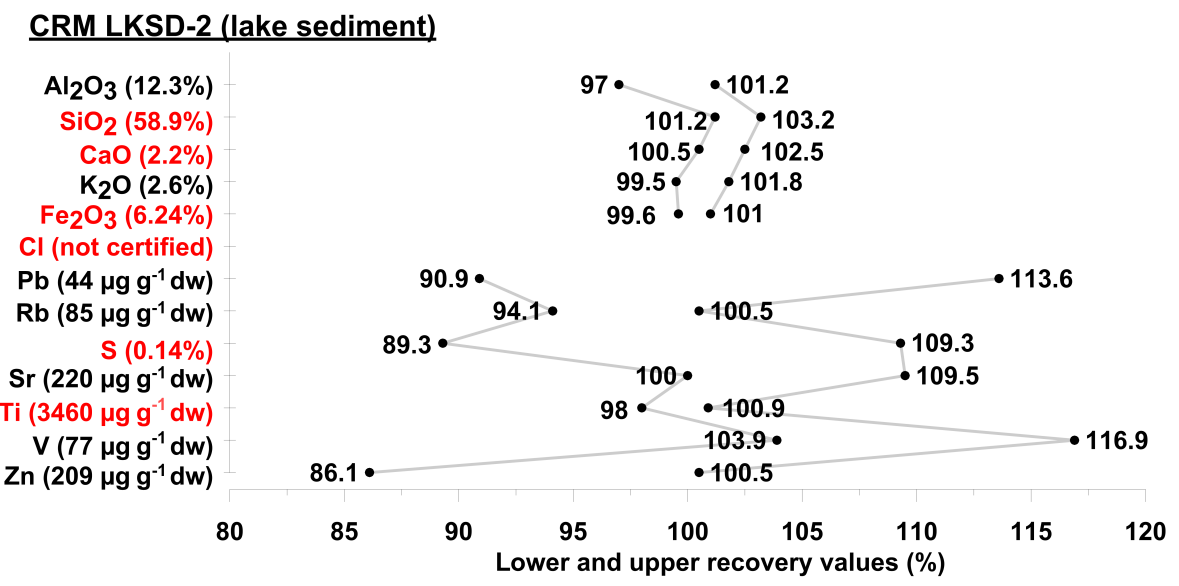

\section{CRM GBW07312 (stream sediment)}

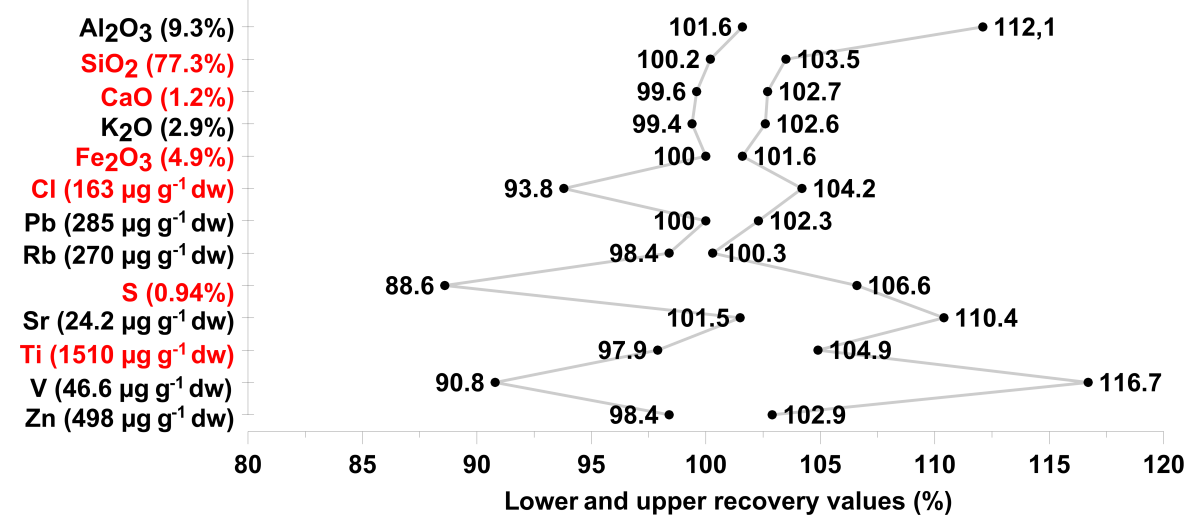

Figure 4. Recovery values (\%) obtained for CRM LKSD-2 (lake sediment) and CRM GBW07312 (stream sediment) by p-ED-XRF analyses. The specified values are shown to the left in parentheses. The elements that were used in the presented study are shown in red.

were macroscopically distinguished due to sedimentary characteristics (Klein et al., 2016) complemented by elemental (TOC content) and p-ED-XRF analysis ( $\mathrm{Ca}, \mathrm{Cl}, \mathrm{Fe}, \mathrm{Ti}, \mathrm{Si}, \mathrm{S})$ (Fig. 5). The latter was used as an integral measure for facies discrimination. To account for sedimentary inhomogeneity and the varying accuracy of the element concentrations obtained by p-ED-XRF analysis, we mainly focus on the interpretation of element ratios to obtain a dimensionless relative tool for the interpretation of different stratigraphic units and facies (Jansen et al., 1998; Richter et al., 2006; Rothwell et al., 2006; Weltje and Tjallingii, 2008).

In coastal systems $\mathrm{Ca}$ input (1) is mainly due to biogenic productivity of calcium carbonate under salt-water marine conditions and (2) is a dissolved component in water. $\mathrm{Fe}$ enriches in terrestrial environments during weathering and soil formation and in sediments predominately indicates hill wash processes in the drainage basin (Schütt, 2004). The $\mathrm{Ca} / \mathrm{Fe}$ ratio can thus be used to differentiate geochemically between marine and terrestrial environments, where high $\mathrm{Ca} / \mathrm{Fe}$ ratios represent marine sediments and low $\mathrm{Ca} / \mathrm{Fe}$ ratios point to terrestrial environments (Vött et al., 2011). XRF-measured $\mathrm{Ca} / \mathrm{Ti}$ ratios are useful for stratigraphic cor- relation between cores even when the variability in concentrations is low (Hennekam and de Lange, 2012), as in core AY05. Si and Ti, like Fe, reflect siliciclastic terrigenous input (Arz et al., 1998, Ramírez-Herrera et al., 2012), and thus lowered $\mathrm{Ca} / \mathrm{Si}$ and $\mathrm{Ca} / \mathrm{Ti}$ ratios also indicate a more terrestrial origin of the sediments. The higher availability of sulfate in seawater than in freshwater results in higher $\mathrm{S}$ contents within brackish/marine depositional environments (Casagrande et al., 1977), and S is used as a geochemical marine marker (Chagué-Goff et al., 2012). Cl in sediments is often used as an indicator for marine conditions (ChaguéGoff, 2010). However, the interpretation of $\mathrm{Cl}$ in our semiterrestrial to coastal sediments is difficult due to the influence of groundwater circulation and the high solubility of $\mathrm{Cl}$. This is shown in relatively large changes in the $\mathrm{Cl}$ content throughout all units without showing any clear trend.

\subsubsection{Unit I}

Unit I extends from the base of the core to $2.30 \mathrm{mb}$ b. and consists of homogenous, weakly compacted pure silt with distinct layers of marine fauna, macro-botanical remains, 


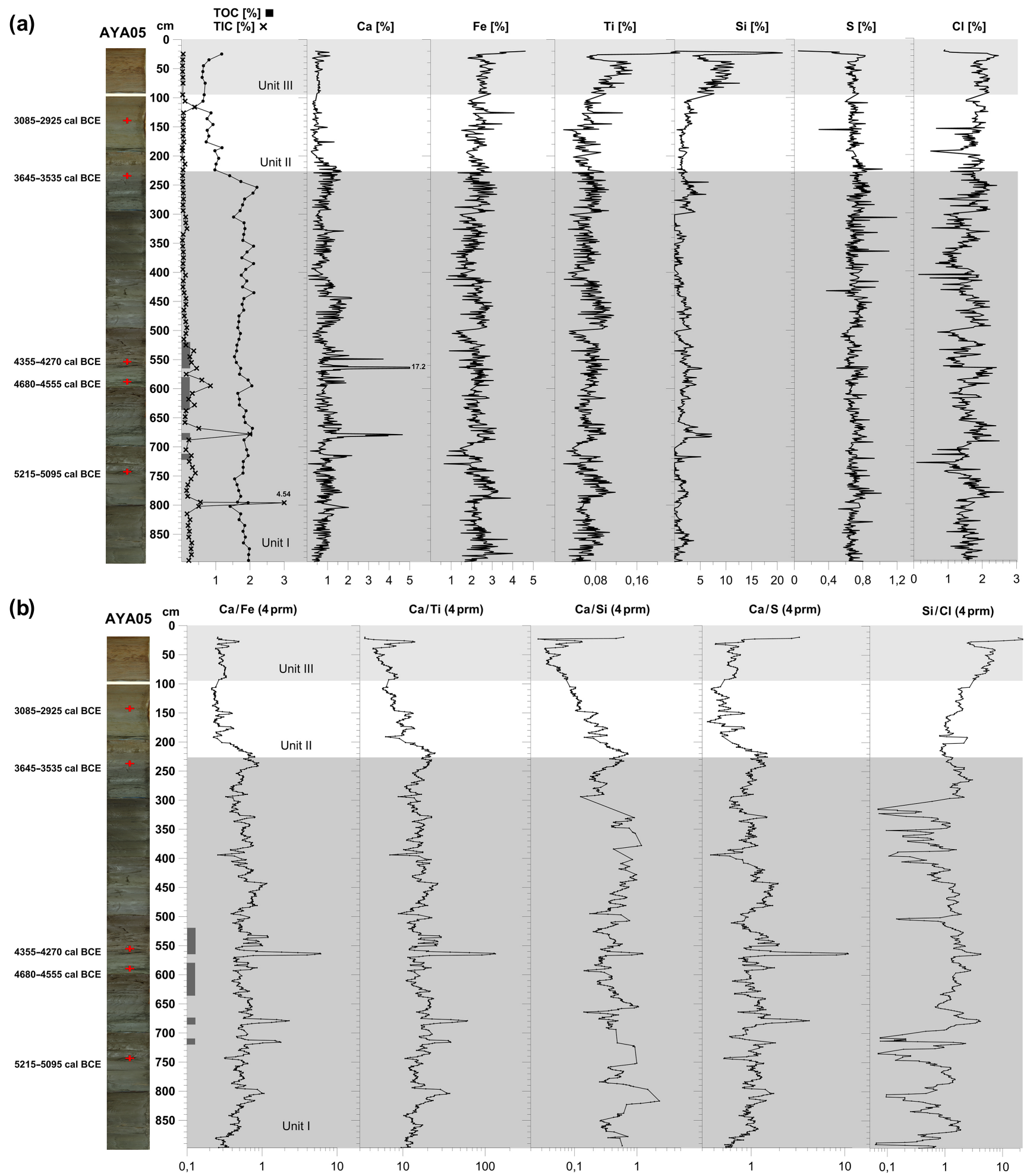

Figure 5. Core AYA-05 with radiocarbon dates, description of the core, and facies interpretation (Unit I to Unit III) based on p-ED-XRF results. (a) p-ED-XRF results measured with the specifications given in Sect. 2.3 for $\mathrm{Ca}, \mathrm{Fe}, \mathrm{Ti}, \mathrm{S}$, and $\mathrm{Cl}$ together with TOC (total organic carbon) contents that were analysed by elemental analysis; (b) four-point running means (4 prm) of $\mathrm{Ca} / \mathrm{Fe}, \mathrm{Ca} / \mathrm{Ti}, \mathrm{Ca} / \mathrm{S}, \mathrm{Ca} / \mathrm{Si}$, and $\mathrm{Si} / \mathrm{Cl}$ ratios. Note the logarithmic scale of the $x$ axis. For a detailed description of the core AYA-05, refer to Figs. S1-S2 in the Supplement and to Klein et al. (2016). 
and charred wood. The organic carbon content with 1.4 to 2.2 mass- $\%$ (mean $=1.8$ mass- $\% ; n=67)$ is relatively high when compared to units II and III. Also the inorganic carbon content is generally slightly higher than in units II and III (mean $=0.28$ mass- $\% ; n=67$ ) and shows highest values up to $4.54 \%$ where shell layers or limestone fragments occur. The Ca content shows mean values around 1.0 mass-\% $(\mathrm{SD}=0.84, n=638)$ varying between 0.1 and 17.2 mass$\%$. The highest $\mathrm{Ca}$ values are measured within the four shell layers and at a depth of $796 \mathrm{~cm}$ due to a limestone fragment. The slightly increased TIC and Ca contents correspond to marine shell fragments. The other elements measured with the p-ED-XRF spectrometer show much lower variation and mean values $(n=638)$ and are as follows: $\mathrm{Fe}=2.25 \%$; $\mathrm{S}=0.69 \% ; \mathrm{Si}=1.36 \% \mathrm{Ti}=0.068 \%$; and $\mathrm{Cl}=1.99 \%$. The ratios $\mathrm{Ca} / \mathrm{Fe}, \mathrm{Ca} / \mathrm{Ti}, \mathrm{Ca} / \mathrm{S}$, and $\mathrm{Ca} / \mathrm{Si}$ show only subtle changes and point to stable conditions in an aquiferous basin partly separated from the open sea (Dabrio et al., 2000). The largest changes are observed in the ratio $\mathrm{Si} / \mathrm{Cl}$, which are due to changes in the $\mathrm{Cl}$ content ( 0.08 to $2.62 \%$ ).

The high contents of organic matter and the low contents of inorganic carbon together with the low Si contents and the greyish colour indicate oxygen-free, reducing conditions and are interpreted as a sub-tidal facies when silt, as a finegrained autochthonous lagoonal deposit, accumulated under sub-aqueous quiescent depositional conditions in a landward lagoonal-like environment.

\subsubsection{Unit II}

Unit II extends from 2.30 to $0.93 \mathrm{~m}$ b.s. and consists of moderately compacted, carbonate-free, greyish-brown pure silt with hydromorphic features. The TOC (mean $=0.84$ mass$\% ; n=14$ ) and TIC contents (mean $=0.08$ mass- $\% ; n=14$ ) are lower than in the underlying unit I, and TOC shows decreasing values towards the top. In contrast to the carbon contents the Ti and Si contents increase within unit II towards the top, as is best seen in the $\mathrm{Si}$ content, which increases from $1.5 \%$ at the unit's base to $5 \%$ in the top layers of unit II. The Ca content $($ mean $=0.56 \% ; n=117)$ is generally lower than in the underlying unit I without showing any trend within unit II. Thus the $\mathrm{Ca} / \mathrm{Ti}$ and $\mathrm{Ca} / \mathrm{Si}$ ratios show a decreasing trend within unit II. The $\mathrm{Ca} / \mathrm{Fe}$ and $\mathrm{Ca} / \mathrm{S}$ ratios are lower than for unit I due to the lower Ca content and similar $\mathrm{Fe}$ and $\mathrm{S}$ contents throughout unit II. The $\mathrm{Si} / \mathrm{Cl}$ ratio shows lower variability in comparison to unit I together with slightly higher values and an increasing trend to the top of unit II. This reflects an increasing Si content towards the top of unit II.

The decrease in Ca content and TIC most probably results from a reduced input of marine organisms (Engel et al., 2010) in consequence of silting-up phases as pointed out by the decreasing trends of the TOC content together with the $\mathrm{Ca} / \mathrm{Ti}$ and $\mathrm{Ca} / \mathrm{Si}$ ratios towards the top of unit II. The brown and silty sediments with the same grain size distribu- tion as unit I are interpreted as salt-marsh deposits, where the mottled character of this unit indicates oxidizing conditions and backs up the interpretation of reduced TOC contents being due to microbial decomposition within an intertidal palaeoenvironment (Weston et al., 2011).

\subsubsection{Unit III}

The uppermost unit, unit III, extends from $0.93 \mathrm{mb}$ b.s. to the top and consists of moderately compacted, brown pure silt. Precipitation of iron oxides, charred wood, and shell fragments from gastropods and molluscs are present throughout unit III. The TOC content increases towards the top from ca. 0.60 to 1.17 mass- $\%$, whereas the TIC contents remain low, similar to unit II. The trend of increasing Ti and Si contents that began in the underlying unit II accelerates within unit III, and the highest values are reached at the top of core AYA05. Mean Si contents $(8.34 \% ; n=67)$ are much higher than the underlying two units, and the highest values reach $21.0 \% \mathrm{Si}$ at the top. The Ti-concentration curve parallels the Si contents and reaches the highest values near the top, with $0.24 \%$ Ti. The $\mathrm{Si} / \mathrm{Cl}$ ratios are highest in unit III due to the increasing $\mathrm{Si}$ contents and $\mathrm{Cl}$ contents within the range of the other units. In consequence of the higher $\mathrm{Si}$ and Ti contents, $\mathrm{Ca} / \mathrm{Si}$ and $\mathrm{Ca} / \mathrm{Ti}$ ratios further decrease in the lower part of unit III before this trend ends, probably due to proceeding soil formation and colluvial deposition. This is corroborated by the Fe contents that remain similar to unit II except for the uppermost samples where higher iron input results from soil-forming processes. Unit III documents the final stage of lagoonal infilling, which is followed by soil formation and colluvial deposition and the influence of terrestrial process dynamics (Klein et al., 2016).

\subsection{Landscape development}

Core AYA05 provides a continuous record of $900 \mathrm{~cm}$ of sediment accumulation and an assessment of late-Holocene processes of sedimentation during the latter phases of postglacial sea-level rise. The high-resolution lithostratigraphical and geochemical study identifies three different palaeoenvironments that span the past 8000 years (Klein et al., 2016). Albeit on generally low levels, elevated $\mathrm{Ca} / \mathrm{Fe}, \mathrm{Ca} / \mathrm{Ti}$, $\mathrm{Ca} / \mathrm{Si}$, and $\mathrm{Ca} / \mathrm{S}$ ratios throughout unit I point to subaqueous depositional conditions in a landward lagoonal-like environment. After the onset of relative sea-level deceleration around $3000 \mathrm{cal}$ BP (Delgado, et al., 2012), the transition from marine (unit I) to amphibious (unit II) conditions took place. Core AYA05 already shows an advanced stage of siltation at that stage - in contrast to other cores investigated in the study area (Klein et al., 2016) - probably due to dynamical lateral changes of the tidal network. The siltingup development is geochemically represented by lowered $\mathrm{Ca}$ contents and an increase in $\mathrm{Si}$ and $\mathrm{Ti}$ and thus decreasing $\mathrm{Ca} / \mathrm{Fe}, \mathrm{Ca} / \mathrm{Ti}$, and $\mathrm{Ca} / \mathrm{Si}$ ratios within unit II. This de- 
trital input resulted presumably from human-induced deforestation and soil erosion (Fletcher et al., 2007; Mendes et al., 2010). This development accelerates in the uppermost $93 \mathrm{~cm}$ of core AYA05 (unit III), and remains of charred wood become more abundant, pointing to colluvial redeposition and increased human pressure on the landscape. At this stage the maritime activities of Phoenician settlers $(\sim 1000 \mathrm{BCE})$ were restricted to the westernmost area directly facing the Guadiana River (Morales, 1997; Klein et al., 2016) as the central core AYA05 and the easternmost core AYA04 were already part of the amphibious zone. The continuous aggradation of organic-rich silt sediments led to a final and complete siltation towards supra-tidal conditions around $1000 \mathrm{CE}$, as documented in Klein et al. (2016).

\section{Conclusions}

The new sample chamber described here allows a portable XRF spectrometer to be used to perform quasi-continuous elemental analyses of a sedimentary sequence of split sediment cores. In this example of use, the results of element concentrations (mainly $\mathrm{Ca}, \mathrm{Fe}, \mathrm{Ti}, \mathrm{Si}, \mathrm{S}$, and $\mathrm{Cl}$ ) and ratios $(\mathrm{Ca} / \mathrm{Fe}$, $\mathrm{Ca} / \mathrm{Ti}, \mathrm{Ca} / \mathrm{Si}, \mathrm{Ca} / \mathrm{S}$, and $\mathrm{Si} / \mathrm{Cl}$ ) were selected to (i) identify stratigraphic units, (ii) differentiate facies changes, and (iii) determine the Holocene sedimentary history of a marine embayment under estuarine conditions. The more than $800 \mathrm{XRF}$ analyses were executed non-destructively without elaborative sample preparation or expensive consumables directly on the dried split surfaces of the sediment cores. The selected element concentrations were monitored and quantified for sufficient accuracy by analysing certified reference material. This new method has been proved to serve as a strong alternative tool where cost-intensive computercontrolled core-scanning XRF devices are not available or where relatively high sedimentation rates require the application of basic XRF instruments with much lower spatial resolution from $0.3 \mathrm{~cm} \times 0.3 \mathrm{~cm}$ to $0.8 \mathrm{~cm} \times 0.8 \mathrm{~cm}$. To reduce the assistance time during measurements of longer sedimentary sequences, the sample chamber could be easily adapted to a computer-controlled stepping motor.

Common portable XRF devices mounted with adapters to the sample chamber introduced here facilitate the low-cost, non-destructive, fast, and semi-continuous analysis of (sediment) cores or other solid samples.

\section{The Supplement related to this article is available online} at doi:10.5194/gi-6-93-2017-supplement.

Competing interests. The authors declare that they have no conflict of interest.
Acknowledgements. The authors thank the excellence cluster EXC264 Topoi (The Formation and Transformation of Space and Knowledge in Ancient Civilizations) of the Deutsche Forschungsgemeinschaft (DFG) for providing funds for the construction of the sample chamber as well as for the fees linked to the German industrial property right. We are also grateful for the support facilitated by the Patent and Licensing Service (PULS) of the Freie Universität Berlin. The sediment cores were provided by the project A-1-7 "Ayamonte" of the EXC264 Topoi of the DFG.

Edited by: L. Eppelbaum

Reviewed by: two anonymous referees

\section{References}

Anonymous: Probenkammer, insbesondere zur Analyse von Sediment- oder Bohrkernproben, Deutsches Patent- und Markenamt 202014106 048.0., 2014.

Arz, H., Pätzold, J., and Wefer, G.: Correlated Millennial-Scale Changes in Surface Hydrography and Terrigenous Sediment Yield Inferred from Last-Glacial Marine Deposits off Northeastern Brazil, Quaternary Res., 50, 157-166, 1998.

Casagrande, D. J., Siefert, K., Berschinski, C., and Sutton, N.: Sulfur in peat-forming systems of the Okefenoke Swamp and Florida Everglades: origins of sulfur in coal, Geochim. Cosmochim. Ac., 41, 161-167, 1977.

Chagué-Goff, C.: Chemical signatures of palaeotsunamis: A forgotten proxy?, Mar. Geol., 271, 67-71, 2010.

Chagué-Goff, C., Andrew, A., Szczuciński, Goff, J., and Nishimura, Y.: Geochemical signatures up to the maximum inundation of the 2011 Tohoku-oki tsunami - Implications for the 869 AD Jogan and other palaeotsunamis, Sediment. Geol., 282, 65-77, 2012.

Dabrio, C. J., Zazo, C., Goy, J. L., Sierro, F. J., Borja, F., Lario, J., Gonzalez, J. A., and Flores, J. A.: Depositional history of estuarine infill during the last postglacial transgression (Gulf of Cadiz, Southern Spain), Mar. Geol., 162, 381-404, 2000.

Delgado, J., Boski, T., Nieto, J.M., Pereira, L., Moura, D., Gomes, A., Sousa, C., and García-Tenorio, R.: Sea-level rise and anthropogenic activities recorded in the late Pleistocene/Holocene sedimentary infill of the Guadiana estuary (SW Iberia), Quaternary Sci. Rev., 33, 121-141, 2012.

Engel, M., Brückner, H., Wennrich, V., Scheffers, A., Kelletat, D., Vött, A., Schäbitz, F., Daut, G., Willershäuser, T., and May, S. M.: Coastal stratigraphies of eastern Bonaire (Netherlands Antilles): new insights into the palaeo-tsunami history of the southern Caribbean, Sediment. Geol., 231, 14-30, 2010.

Fletcher, W. J., Boski, T., and Moura, D.: Palynological evidence for environmental and climatic change in the lower Guadiana valley, Portugal, during the last 13000 years, Holocene, 17, 481-494, 2007.

Hennekam, R. and de Lange, G.: X-ray fluorescence core scanning of wet marine sediments: methods to improve quality and reproducibility of high-resolution palaeoenvironmental records, Limnol. Oceanogr.-Meth., 10, 991-1003, doi:10.4319/lom.2012.10.991, 2012.

Jansen, J. H. F., van der Gaast, S., Koster, B., and Vaars, A. J.: CORTEX, a shipboard XRF scanner for element analyses in split sediment cores, Mar. Geol., 151, 143-153, 1998. 
Kido, Y., Koshikawa, T., and Tada, R.: Rapid and quantitative major element analysis method for wet fine-grained sediments using an XRF microscanner, Mar. Geol., 229, 209-225, 2006.

Klein, T., Bebermeier, W., Krause, J., Marzoli, D., and Schütt, B.: Sedimentological evidence of an assumed ancient anchorage in the hinterland of a Phoenician settlement (Guadiana estuary/SWSpain), Quatern. Int., 407, 110-115, 2016.

Koshikawa, T., Kido, Y., and Tada, R.: High-resolution rapid elemental analysis using an XRF microscanner, J. Sediment. Res., 73, 824-829, 2003.

Lynch, J.: Provisional Elemental values for eight new geochemical lake sediment and stream sediment reference materials LKSD1, LKSD-2, LKSD-3, LKSD-4, STSD-1, STSD-2, STSD-3 and STSD-4, Geostandard. Newslett., 14, 153-167, 1990.

Mendes, I., Rosa, F., Dias, J. A., Schönfeld, J., Ferreira, O., and Pinheiro, J.: Inner shelf paleoenvironmental evolution as a function of land-ocean interactions in the vicinity of the Guadiana River, SW Iberia, Quatern. Int., 221, 58-67, 2010.

Morales, J. A.: Evolution and facies architecture of the mesotidal Guadiana River delta (S.W. Spain-Portugal), Mar. Geol., 138, 127-148, 1987.

Ramírez-Herrera, M. T., Lagos, M., Hutchinson, I., Kostoglodov, V., Machain, M. L., Caballero, M., Goguitchaichvili, A. Q., Aguilar, B., Chagué-Goff, C., Goff, J., Ruiz-Fernández, A.-C., Ortiz, M., Nava, H., Bautista, F., Lopez, G. I., and Quintana, P.: Extreme wave deposits on the Pacific coast of Mexico: Tsunamis or storms? - A multi-proxy approach, Geomorphology, 139-140, 360-371, 2012.

Richter, T. O., van der Gaast, S., Koster, B., Vaars, A., Gieles, R., de Stigter, H. C., de Haas, H., and van Weering, T. C. E.: The Avaatech XRF Core Scanner: Technical description and applications to NE Atlantic sediments, in: New Techniques in Sediment Core Analysis, edited by: Rothwell, G., Geol. Soc. Spec. Publ., 267, 39-50, 2006.
Rothwell, R. G., Hoogakker, B., Thomson, J., Croudace, I. W., and Frenz, M.: Turbidite emplacement on the southern Balearic Abyssal Plain (western Mediterranean Sea) during Marine Isotope Stages 1-3: an application of ITRAX XRF scanning of sediment cores to lithographic analysis, in: New techniques in sediment core analysis, edited by: Rothwell, R. G. and Rack, F. R., Geol. Soc. Spec. Publ., 267, 79-98, 2006.

Schütt, B.: Zum holozänen Klimawandel der zentralen Iberischen Halbinsel, Relief, Boden, Paläoklima, 20, SChweizerbart, Stuttgart, Germany, 2004.

Schwanghart, W., Bernhardt, A., Stolle, A., Hoelzmann, P., Adhikari, B. R., Andermann, C., Tofelde, S., Merchel, S., Rugel, G., Fort, M., and Korup, O.: Repeated catastrophic valley infill following medieval earthquakes in the Nepal Himalaya, Science 351, 147-150, doi:10.1126/science.aac9865, 2016.

Teyssandier, E. G. and Marzoli, D.: Phönizische Gräber in Ayamonte (Huelva, Spanien), Ein Vorbericht, Deutsches Archäologisches Institut, Madrid, Spain, 2014.

Vött, A., Bareth, G., Brückner, H., Lang, F., Salelariou, D., Hadler, H., Ntageretzis, K., and Willershäuser, T.: Olympia's Harbour Site Pheia (Elis, Western Peleponnese, Greece) Destroyed by Tsunami Impact, Die Erde, 142, 256-288, 2011.

Weltje, G. J. and Tjallingii, R.: Calibration of XRF core scanners for quantitative geochemical logging of sediment cores: Theory and application, Earth Planet. Sc. Lett., 274, 423-438, doi:10.1016/j.epsl.2008.07.054, 2008.

Weston, N. B., Vile, M. A., Neubauer, S. C., and Velinsky, D. J.: Accelerated microbial organic matter mineralization following saltwater intrusion into tidal freshwater marsh soils, Biogeochemistry, 102, 135-151, doi:10.1007/s10533-010-9427-4, 2011. 